\title{
Kehidupan Tokoh Fukiko Sebagai Single Mother di Pulau Sae yang Tercermin pada Novel Shima Wa Bokura To Karya Mizuki Tsujimura
}

\author{
Ni Wayan Intan Kurnia Sari ${ }^{*}$, Ni Luh Putu Ari Sulatri, Ni Putu Luhur Wedayanti \\ Program Studi Sastra Jepang Fakultas Ilmu Budaya \\ [tand_kurnia@yahoo.co.id], [ari_sulatri@unud.ac.id], [luhur_wedayanti@unud.ac.id] \\ *Corresponding Author
}

\begin{abstract}
The title of this paper is "The Life of Fukiko As Single Mother in Sae Island that Reflected in a Novel Called Shima Wa Bokura To by Mizuki Tsujimura". The aim of this research is analysis the problems that Fukiko has to face as a single mother and her efforts to resolve these that reflected in a novel called Shima Wa Bokura To by Mizuki Tsujimura. The method used in this research is descriptive analysis. Theories used in this research are literature sociology theory by Damono (2002) and social problem theory by Soekanto (1999).As a result, there are four problems that Fukiko has to face as a single mother; 1) economic problems; 2) difficulty in raising children; 3) rejection by her family and; 4) viewed negatively by society. Fukiko's efforts as a single mother to resolve problems that mentioned before; 1) make a creative products to sell; 2) ask her neighbor to help; 3) get out from her family's and start a new life, and; 4) face them with patient and politely.
\end{abstract}

Keywords: Single Mother, Social Life, Social Problem

\begin{abstract}
Abstrak
Skripsi ini berjudul "Kehidupan Tokoh Fukiko Sebagai Single Mother Di Pulau Sae Yang Tercermin Pada Novel Shima Wa Bokura To Karya Mizuki Tsujimura". Penelitian ini bertujuan untuk mengetahui permasalahan yang dihadapi tokoh Fukiko sebagai single mother serta upaya-upaya dalam mengatasi permasalahan tersebut yang tercermin pada novel Shima Wa Bokura To Karya Mizuki Tsujimura. Metode yang digunakan dalam penelitian adalah metode deskriptif analisis. Penelitian ini menggunakan teori sosiologi sastra menurut Damono (2002) dan teori masalah sosial menurut Soekanto (1999). Berdasarkan hasil penelitian terdapat empat permasalahan yang dihadapi tokoh Fukiko sebagai single mother. Permasalahan yang dihadapi tersebut antara yaitu; 1) mengalami masalah ekonomi; 2) mengalami kesulitan dalam merawat anak; 3) mengalami penolakan dari keluarga, dan; 4) mendapat pandangan buruk dari masyarakat. Upaya-upaya tokoh Fukiko sebagai single mother dalam menghadapi permasalahan yang telah disebutkan sebelumnya, yaitu; 1) dengan cara membuat produk kreatif untuk dipasarkan; 2) dengan cara menerima bantuan tetangga dan berusaha merawat anaknya secara mandiri; 3) dengan cara pergi meninggalkan keluarga dan memulai kehidupan baru, dan; 4) dengan cara mengahadapinya dengan sabar serta sopan.
\end{abstract}

Kata kunci : Single Mother, Kehidupan Sosial, Masalah Sosial 


\section{Pendahuluan}

Single mother merupakan kondisi ibu sebagai satu-satunya orang tua dalam keluarga yang berperan penting dalam membesarkan anaknya (Rahmat, 2001:12). Ibu sebagai orang tua tunggal lebih membatasi kehidupan sosialnya dibandingkan seorang ayah, dan karena hilangnya seseorang yang akan menjadi contoh dan panutan bagi anak-anak (Trisna, 2013:30). Kesulitan menjadi single mother dialami oleh tokoh Fukiko dalam novel Shima wa Bokura to karya Mizuki Tsujimura. Fukiko merupakan seorang single mother yang disebabkan oleh faktor hamil di luar nikah. Masalah yang dihadapinya yaitu, kesulitan dalam merawat anak, kesulitan ekonomi karena harus mengurus anak, mendapat pandangan yang buruk dari masyarakat sekitar, dan lain sebagainya. Dalam menghadapi kendala tersebut, beberapa upaya dilakukan oleh tokoh Fukiko sebagai single mother pada novel Shima wa Bokura to karya Mizuki Tsujimura. Upaya tersebut salah satunya yang dilakukan tokoh Fukiko saat mengalami kesulitan merawat anaknya adalah menerima bantuan dari tetangganya.

\section{Pokok Permasalahan}

a. Bagaimanakah permasalahan yang dihadapi oleh tokoh Fukiko sebagai single mother di Pulau Sae yang tercermin dalam novel Shima wa Bokura to karya Mizuki Tsujimura?

b. Bagaimanakah cara tokoh Fukiko mengatasi permasalahan yang dihadapi sebagai single mother di Pulau Sae yang tercermin dalam novel Shima wa Bokura to karya Mizuki Tsujimura?

\section{Tujuan Penelitian}

Tujuan penelitian ini adalah untuk mengetahui permasalahan yang dihadapi oleh tokoh Fukiko sebagai single mother pada novel Shima wa Bokura to karya Mizuki Tsujimura dan upaya tokoh
Fukiko sebagai single mother dalam mengatasi permasalahan yang dihadapinya yang tercermin dalam novel Shima wa Bokura to karya Tsujimura (2013).

\section{Metode Penelitian}

Metode yang digunakan dalam penelitian adalah metode deskriptif analisis. Penelitian ini menggunakan teori sosiologi sastra menurut Damono (2002) sebagai payung utama penelitian untuk menganalisis masalah yang dihadapi tokoh-tokoh single mother dan upaya dalam mengatasi masalah tersebut. Serta didukung oleh teori masalah sosial menurut Soekanto (1999).

\section{Hasil dan Pembahasan}

Berikut ini adalah hasil pembahasan mengenai permasalahan yang dihadapi oleh tokoh Fukiko sebagai single mother serta upaya mengatasi pemasalahan tersebut.

\subsection{Permasalahan Yang Dihadapi Oleh Tokoh Fukiko Sebagai Single Mother Di Pulau Sae Pada Novel Shima Wa Bokura To Karya Mizuki Tsujimura}

\subsubsection{Mengalami Masalah Ekonomi}

Adapun berikut data yang menunjukkan bahwa Fukiko mengalami kesulitan Ekonomi dalam hal mencari pekerjaan.

(1) 蕗子と朱里の母新である明美は、

同じ食料加工会社で働いている。 その名も、『さえじま』。会社 といっても、公民館のような場 所にその時々集まって、魚の一 夜干しや海苔の佃煮を作る。シ ングルマザーの受け皿になる、 
と言っても、職が限られた数し かない島の中で、五年前、大矢 村長が島のおばちゃんたちを集 め、作ることを勧めた会社が 『さえじま』だ。

Fukiko to shuri no haha oya de aru Akemi wa, onaji shoku ryou kakou kaisha de hataraiteiru. Sono na mo, "Saeijima". Kaisha to ite mo, kouminkan no youna bahso ni sono toki doki atsumatte, sakana no ichiyaho shiya nori no tsukudani o tsukuru. Singuru majhaa nu uke sara ni naru, to itte mo, shoku ga kagirareta kazushikanai shima no naka de, go nen mai, ooya shonchou ga shima no obachan tachi o atsume, tsukuru koto o susumeta kaisha ga "Saejima" da.

(Shima wa Bokura, 2013:21)

Terjemahan:

Fukiko dan Akemi, ibu Akari, samasama bekerja di pabrik pengolahan makanan. Perusahaan itu diberi nama Saejima. Sebenarnya, tempat itu lebih tepat disebut balai masyarakat karena mereka hanya sesekali berkumpul untuk menggarami serta mengeringkan ikan semalam. Lima tahun lalu, Kepala Desa Ooya mengumpulkan para wanita di pulau itu dan mengusulkan mnendirikan Saejima mengingat terbatasnya pekerjaan.

Data (1) merupakan data yang menunjukkan bahwa Fukiko dan Akemi mengalami masalah Ekonomi karena terbatasnya lapangan kerja. Fukiko dan Akemi hanya bekerja di sebuah pabrik pengolahan makanan yang dinamakan Saejima. Perusahaan tersebut sengaja didirikan untuk mempekerjakan ibu-ibu di Pulau Sae agar mendapat uang untuk kebutuhan mereka sehari-hari. Meski penghasilan yang diperoleh tidak tetap karena tergantung pada jumlah ikan yang ditangkap, ibu-ibu di sana tetap bertahan bekerja di Saejima. Hal tersebut disebabkan karena terbatasnya lapangan kerja di Pulau Sae.

\subsubsection{Mengalami Kesulitan Dalam Merawat Anak}

Adapun berikut data yang menunjukkan permasalahan yang dihadapi tokoh Fukiko saat merawat anaknya yang sedang sakit sendirian.

(2) 目を半眼にして「気持ち、悪い」 と船の摇れに耐えている。こう やて見ると、ーロに補助金が出 ると言っても、病気の子どもを 連れて島から本士に渡るという ことはお母さん一人の家庭にと つては大仕事なのだなあと悪い

知る。

Me o hangan ni shite kimochi, warui to fune no taete iru. Kouyatte miru to, ichiro hojhokin ga deru to itte mo, byouki no kodomo o tsurete shima kara honshi wataru toiu koto wa okaasan hitori no katei ni totte wa daishigotona no danaa to warui shiru.

(Shima wa Bokura, 2013:212)

Terjemahan:

"Aku mual", katanya dengan mata setengah terpejam, menahan guncangan kapal. Melihat kondisi ini,betapa besar tugas seorang ibu rumah tangga yang harus membawa anaknya yang sakit dari pulau menuju daratan utama, kendati mereka juga mendapat subsidi. 
Data (2) menunjukkan bahwa tokoh Fukiko kerepotan mengurus anaknya Mina ketika sedang sakit. Mina yang masih kecil harus diajak menyeberang ke luar pulau untuk mendapata perawatan medis. Pada data (2) Mina mengungkapkan pada ibunya bahwa ia merasa mual ketika sedang berada di atas kapal laut, dalam perjalanan menuju daratan utama. Pada data (2) juga disebutkan betapa besarnya tugas Fukiko sebagai single mother saat membawa anaknya yang sedang sakit bepergian jauh ke luar pulau. Pada data (2) dapat dianalisis bahwa tokoh Fukiko mengalami kesulitan saat anaknya sedang sakit, karena ia harus membawa anaknya sendirian menyeberang keluar pulau untuk mendapat perawatan medis.

\subsubsection{Mengalami Penolakan dari Keluarga}

Adapun berikut data yang menunjukkan bahwa kehamilan Fukiko tidak diterima oleh orang tuanya, sehingga ia memutuskan untuk pergi meninggalkan rumah.

（3）蕗子を学生時代から導いてきた というその人は、中国人の元才 リンピック選手で、そのことに ついて、蕗子の両親は烈火のご とく怒り狂った。しかしその怒 りは相手ではなく、ただただ身 内のみに向けられるものだった。 蕗子を怒り、認められないと言 つた。外国人との結婚も、不倫 も、子どもを産むことも。

Fukiko o gakusei jidai kara michibi itekita toiu sono hito wa, chuugokujin no moto orinpikku senshu de, sono koto ni tsuite,
Fukiko no ryoushin wa rekka no gotoku ikari totta. Shikashi sono ikari wa aite dewa naku, tada tada miuchi no mini mukerareru mono datta. Fukiko o ikari, mitomerarenai to itta. Gaikokujin to no kekkon mo, furin mo, kodomo o umukotomo.

(Shima wa Bokura, 2013:131)

Terjemahan:

Orang tua Fukiko marah besar saat mengetahui pelatih yang telah membimbing Fukiko sejak masa sekolah itu manta atlet Olimpiade asal China. Namun, kemarahan mereka bukan ditujukan pada pria itu, melainkan pada Fukiko. Mereka berkata tidak akan mengakui baik itu pernikahan dengan orang asing, perselingkuhan, sampai fakta bahwa putri mereka sedang mengandung.

Data (3) merupakan data yang menunjukkan bahwa kehamilan Fukiko tidak diterima oleh orang tuanya, karena ia hamil di luar nikah dengan pelatih renangnya yang telah beristri. Diceritakan pada novel ini Fukiko yang seorang atlet renang terkenal hamil di luar nikah dengan pelatih renangnya sendiri yang telah memiliki isteri. Mendengar hal tersebut orang tua Fukiko sangat marah dan tidak mau menerima kehamilan Fukiko. Bahkan mereka juga tidak menerima perselingkuhan Fukiko dengan pelatihnya hingga tidak mau Fukiko menikah dengan pelatihnya tersebut.

\subsubsection{Mendapat Pandangan Buruk dari Masyarakat}

Adapun berikut data yang menunjukkan bahwa Fukiko menjadi topik pembicaraan orang-orang di sekitarnya karena hamil di luar nikah dan pindah ke pulau Sae tanpa seorang suami. 
(4) そんな島のシングルマザーたちの 事情の中でも、蕗子のものはま た格別に有名だ。相手の男のこ とだけならば聞かない話ではな いかもしれないが、島に移り住 むことになった経緯の方が特殊 だった。

Sonna shima no singurumajhaa tachi jijou no naka demo, Fukiko no mono ha mata kakubetsu ni yuumei da. Aite no otoko no koto dake naraba kikanai hanashi dewanai kamoshirenai ga, shima ni utsuri sumu koto ni natta keii no kata ga tokushu datta

(Shima wa Bokura, 2013:117)

Terjemahan:

Di antara situasi yang dialami para ibu tunggal di Pulau Sae, kasus Fukiko lah yang paling populer. Meski ia tidak pernah membahas siapa pasangannya, kepindahannya ke pulau inilah yang paling mencuri perhatian.

Data (4) merupakan data yang menunjukkan bahwa tokoh Fukiko menjadi topik pembicaraan orang-orang di sekitarnya, karena hamil di luar nikah. Diceritakan pada novel ini Fukiko hamil di luar nikah dengan guru renangnya yang telah memiliki isteri. Saat sedang hamil Fukiko merupakan atlet renang terkenal yang sering tampil di media. Takut kehamilannya menjadi aib keluarga, akhirnya Fukiko memutuskan untuk meninggalkan rumahdan orang tuanya. Fukiko memutuskan pindah ke Pulau Sae untuk menutupi aibnya dan memulai kehidupan yang baru di sana. Namun, kepindahannya ke pulau Sae tidak dapat meredakan pembiicaraan orang mengenai dirinya. Sebagaian masyarakat di Pulau Sae mengenalinya karena saat itu ia sering terliput media berkat prestasi yang dimilikinya sebagai atlet renang. Pada saat baru pertama kali datang ke Pulau Sae ia tidak luput dari topik pembicaraan karena kehamilannya tanpa suami. Pada data (4) dapat dianalisis bahwa, Fukiko memiliki masalah yaitu dibicarakan oleh masyarakat sekitar Pulau Sae karena kehamilannya di luar nikah.

\subsection{Upaya Tokoh Fukiko Sebagai Single Mother Dalam Mengatasi Permasalahan Yang Dihadapinya Yang Tercermin Dalam Novel Shima Wa Bokura To Karya Mizuki Tsujimura}

Upaya yang dilakukan untuk mengatasi permasalahan atau kendala yang dihadapi tokoh-tokoh single mother pada novel Shima wa Bokura dijelaskan pada anak sub bab di bawah ini, sebagai berikut.

\subsubsection{Menciptakan Produk Jual yang Kreatif}

Adapun berikut data yang menunjukkan bahwa para single mother mengatasi masalah ekonomi yang dihadapi dengan menciptakan produk yang menarik untuk dipasarkan.

(5) 島の漁業組合や農協には、村長が

話をつけてくれた。おばちやん たちは、所謂アウトレット品の ような形が悪いせいで売り物に ならない魚やみかんを安価で仕 人れ、それを見栄えよく佃煮や ジャムの形に加工して出荷する。

Shima no gyogyou kumi ai ya noukyo ni wa, shoncou ga hanashi o tsukete kureta. Obachaan tachi wa, iwayuru 
autoretto shina no youna katachi ga warui seite uri mono ni naranai sakana ya mikan o anka de tsukouhito re, sorre o mibae yoku tsukudani ya jhamu no katachi ni kakou shite shukka suru.

(Shima wa Bokura, 2013:37)

Terjemahan:

Kepala Desa sudah mengatur segala sesuatunya dengan Asosiasi Pengolahan Ikan dan Koperasi Pertanian. Ibu-ibu di pulau itu diminta mengolah ikan dan jeruk yang tampilan luarnya tidak meyakinkan menjadi tsukudani dan selai yang enak dipandang untuk dijual.

Data (5) merupakan data yang menunjukkan bahwa para single mother di Pulau Sae yang tercermin pada novel Shima wa Bokura to mengatasi masalah ekonomi mereka dengan mengembangkan perusahaan Saejima. Atas arahan kepala desa dan bimbingan dari Asosiasi Pengolahan Ikan serta Koperasi Pertanian dari daratan utama, mereka berhasil membuat tsukudani dan selai yang dikemas dengan menarik untuk dipasarkan dalam jumlah yang lebih besar. Jika jumlah penjualan meningkat tentu penghasilan mereka pun meningkat. Hal tersebut dapat mengatasi masalah ekonomi yang dihadapi selama ini khususnya memperluas lapangan kerja bagi masyarakat di Pulau Sae.

\subsubsection{Menerima Bantuan dari Orang- Orang Terdekat}

Adapun berikut data yang menunjukkan bahwa Fukiko dibantu oleh Akari dan keluarganya sejak mengandung hingga merawat Mina setelah lahir.

（6）蕗子が引つ越してきて、出産と 育児を見守った。朱里の家がー
番近いから、朱里も、母も新母

も、蕗子と末莱を第二の家族の

ように思ってきた。

Fukiko ga ikkou shite kite, shussan to ikuji o mimamotta. Jhuri ni ie ga ichiban chikai kara, shuri mo, haha mo shinhaha mo, Fukiko to mirai o daini no kazoku nouni omotte kita.

(Shima wa Bokura, 2013:57)

Terjemahan:

Sejak pindah ke pulau dalam keadaan mengandung hingga melahirkan, baik Akari, ibu, maupun neneknya, selalu menjaga Fukiko karena rumah mereka yang paling dekat dengan rumah Fukiko. Mereka sudah menganggapnya seperti anggota keluarga sendiri.

Data (6) merupakan data yang menunjukkan bahwa Fukiko selalu dibantu oleh tetangganya Akari serta keluarganya, dalam merawat anaknya Mina. Pada data (6) dijelaskan bahwa Akari dan keluarganya selalu menjaga dan membantu Fukiko sejak ia mengandung hingga merawat anaknya Mina setelah lahir. Fukiko sudah dianggap seperti keluarga mereka sendiri, sehingga mereka merasa bertanggungjawab terhadap Fukiko. Mendapat perlakuan yang sangat baik, Fukiko kadang merasa canggung terhadap keluarga Akari. Dapat dianalisis pada data (6) bahwa Fukiko mengatasi kesulitan merawat anaknya dengan cara menerima bantuan dari orang-orang terdekatnya yaitu Akari beserta keluarganya. Pada data (6) dijelaskan bahwa Fukiko mendapat bantuan sejak ia datang ke Pulau Sae dalam keadaan mengandung. 


\subsubsection{Pergi Meninggalkan Orang Tua}

Adapun berikut data yang menunjukkan bahwa Fukiko mengatasi penolakan dari keluarga dengan cara melarikan diri.

(7) 蕗子自身には、まつたく関係の ない事柄のはずだった。けれど、 これを読んだ時に一番激しく、 蕗子の胸かき乱された。震えた。 そして決断したのだ。逃げなけ ればならないと。

Fukiko jishin niwa, mattaku kankei no nai kotogara no hazudatta. Keredo, kore o yonda toki ni ichiban hageshiku, Fukiko no mune kaki midasareta. Furueta. Sishite ketsudan shita no da. Nige nakereba naranai to. (Shima wa Bokura, 2013:35)

Terjemahan:

Seharusnya hal itu tidak perlu memengaruhi Fukiko. Namun, saat membaca surat itu, justru hatinyalah yang paling terguncang. Tubuhnya gemetar. Akhirnya ia memutuskan, ia harus melarikan diri.

Data (7) merupakan data yang menunjukkan bahwa Fukiko mengatasi penolakan dari keluarganya dengan cara pergi dan menghindari keluarganya. Pada data (7) diceritakan bahwa Fukiko baru saja selesai berkonflik dengan orang tuanya karena kehamilannya. Saat merasa bingung sedih, Fukiko membaca sebuah surat kabar tentang kematian seorang perempuan bunuh diri karena mengalami penolakan dari keluarga dan masyarakat sekitar akibat kehamilannya di luar nikah. Setelah membaca surat kabar tersebut, Fukiko merasa bahwa dirinya berada pada posisi tersebut. Ia tidak mau terus- terusan bertengkar dengan orang tuanya, dan tidak mau membuat aib di keluarga.

\subsubsection{Bersikap Baik dan Sopan}

Adapun berikut data yang menunjukkan bahwa Fukiko menghadapi cemooh masyarakat dengan tenang dan sopan.

（8）島のみんなが、役場に入る臨寺 職員の人たちを、「電話の受け 答えで、『お待ちください』つ て敬語使われたんよ」、「丁寧 でかしこまっとる」と良い方に も悪い方にも言って騒ぐのを、 ふうん、というくらいの気持ち で聞いていたけれど、ああ、そ れって、こういう人たちがやつ ていたんだ、と妙に納得し、そ れから無性に悔しくなつた。

Shima no minna ga, yakuba ni ireru nozomu tera shokuin no hito tachi o, "denwa no uke aede, 'omachi kucasai' tte keigotsukawaretanyo", "teinei de kashikomattoru" to nagai kata nimo warui kata nimo itte sawagu no o, fuun, toiu kurai no kimochi de kiite ita keredo, aa, sorette, kouiu hitotachi ga yatte itanda, to myou ni nattoku shi, sore kara mushou ni kuyashikunatta.

(Shima wa Bokura, 2013:38-39)

Terjemahan:

Akari tidak pernah ambil pusing saat pertama kali mendengar komentar warga pulau tentang betapa sopannya Fukiko. Menurut mereka, cara bicara Fukiko sama seperti staf Balai Kota saat menerima telepon menggunakan bahasa formal yang 
sempurna, misalnya "Mohon tunggu sebentar," atau menghindari cara bicara yang buruk dengan menggunakan bahasa yang sopan.

Data (8) merupakan data yang menunjukkan bahwa Fukiko menghadapi pandangan negatif masyarakat dengan tenang dan sopan. Pada data (8) diceritakan bahwa Fukiko selalu menjawab pertanyaan atau berbicara sopan dengan masyarakat di sekitarnya. Kedatangan awalnya menjadi topik pembicaraan yang kurang baik karena ia seorang atlet renang terkenal yang hamil di luar nikah. Menghadapi hal tersebut Fukiko tetap terlihat tenang dan berusaha mengakrabkan diri dengan lingkungan sekitarnya.

\section{Simpulan}

Berdasarkan hasil pembahasan dapat disimpulkan bahwa terdapat empat permasalahan yang dihadapi tokoh Fukiko sebagai single mother. Permasalahan yang dihadapi tersebut antara yaitu. Pertama mengalami masalah ekonomi. Kedua mengalami kesulitan dalam merawat anak. Ketiga mengalami penolakan dari keluarga, dan keempat mendapat pandangan buruk dari masyarakat. Upaya-upaya tokoh Fukiko sebagai single mother dalam menghadapi permasalahan yang dihadapi yaitu. Pertama upaya menghadapi masalah ekonomi dengan cara membuat produk kreatif untuk dipasarkan. Kedua upaya mengatasi kesulitan merawat anak dengan cara menerima bantuan tetangga dan berusaha merawat anaknya secara mandiri. Ketiga upaya mengatasi penolakan dari keluarga dengan cara pergi meninggalkan keluarga dan memulai kehidupan baru, dan keempat upaya mengatasi pandangan buruk dari masyarakat dengan cara mengahadapinya dengan sabar serta sopan.

\section{Daftar Pustaka}

Damono, Suparsi Djoko. 2002. "Pedoman Penelitian Sastra". Jakarta: Pusat Bahasa Departemen Pendidikan Nasional

Rahmat, DJ. 2001. Psikologi Komunikasi. Edisi Revisi. Bandung: CV. Remaja Rosdakarya

Soekanto, Soerjono. 1999. "Pengantar Penelitian Hukum”. Jakarta: Universitas Indonesia Press.

Trisna, dwiyanti. 2013. "Masalah Sosial Masyarakat Jepang Pasca Perang Dunia II Dalam Novel Saga no Gabai Baachan Karya Yoshichi Shimada”. (skripsi). Yogyakarta: Universitas Gajah Mada.

Tsujimura. Mizuki. 2013. "Shima wa Bokura to". Tokyo: Ltd. Kondansha 